\title{
Fertility of dairy heifers given a commercial diet free of $\beta$-carotene*
}

\author{
BY Y. FOLMAN, I. ASCARELLI, $†$ Z. HERZ, M. ROSENBERG, \\ M. DAVIDSON AND A. HALEVI \\ Institute of Animal Science, Agricultural Research Organization, The Volcani Center, \\ Bet Dagan, Israel and $\dagger$ The Faculty of Agriculture, Hebrew University of \\ Jerusalem, Rehovot, Israel
}

(Received 28 June 1978 - Accepted I3 September 1978)

I. Dairy heifers given concentrates including vitamin A and wheat straw from 7 to 17 months of age had an average plasma $\beta$-carotene concentration of $20-60 \mu \mathrm{g} / \mathrm{l}$. Control heifers given the same diet but supplemented with $\beta$-carotene had a $\beta$-carotene plasma concentration of $630-2190 \mu \mathrm{g} / \mathrm{l}$.

2. In contrast to previous findings no differences in duration of standing oestrus, length of oestrous cycle, plasma progesterone and luteinizing hormone $(\mathrm{LH})$ concentrations and interval between $\mathbf{L H}$ peak and ovulation were observed between the groups. All the heifers conceived after one or two inseminations; conception rate being $69 \%$ for heifers given a diet free of $\beta$-carotene and $78 \%$ for the controls.

3. Average rate of growth of heifers not supplemented with $\beta$-carotene was $0.75 \pm 0.02 \mathrm{~kg} / \mathrm{d} v .0 .81 \pm 0.02$ $\mathrm{kg} / \mathrm{d}$ for the controls $(P \leqslant 0.02)$.

4. The possible reasons for the discrepancy between present and previous findings are discussed.

It was recently reported that feeding dairy heifers a diet with a low $\beta$-carotene content impairs some reproductive functions of the animals (Meyer et al. 1975; Lotthamer et al. 1976; Schams et al. 1977). Among the findings reported were an increase in the number of follicular and luteal cysts, changes in the pattern of sexual behaviour, an increase in the interval between the lutenizing hormone (LH) peak and ovulation and a decrease in conception rates. These findings are of great practical importance since in many parts of the world, as in Israel where green forages and hay are scarce and expensive, many heifers are raised on concentrates, various by-products and straw supplemented with vitamins and minerals. Since the only function attributed to $\beta$-carotene was that of a precursor to vitamin A, the supplementation of this carotenoid is not officially recommended ((UK) Agricultural Research Council, 1965; (US) National Research Council, 1971). The aim of the present study was to investigate reproductive phenomena in dairy heifers given a concentrate and straw diet. Such a diet, which is common on many farms in Israel, has presumably a lower $\beta$-carotene content than the diets fed in the previously mentioned experiments where concentrates and old hay were fed.

\section{EXPERIMENTAL}

\section{Animals and diet}

Twenty dairy heifers of the Israeli-Friesian breed were allocated, according to age and body-weight, to the experimental and control groups of twelve and eight heifers, respectively. One heifer of the control group died from malignant oedema (Clostridium septicum); another heifer from the experimental group was removed from the experiment after a general infection, loss of appetite and loss of body-weight during 2 months. At the beginning

* Contribution from the Agricultural Research Organization, The Volcani Center, Bet Dagan, Israel, 1978 series, no. I74-E.

$\ddagger$ Hahaklait, Rishon LeZion, Israel. 
of the experiment the average age of the heifers was 7 months and their body-weight was $169 \mathrm{~kg}$.

The two groups were kept in separate pens on slatted floors in an open shed with adjacent yards. During the whole experimental period the heifers were group fed an average of $4.5 \mathrm{~kg}$ concentrates and $2.1 \mathrm{~kg}$ wheat straw daily to allow a growth rate of $0.75 \mathrm{~kg} / \mathrm{d}$. During the feeding of concentrates they were stanchioned for approximately $2 \mathrm{~h}$ daily. The concentrates contained $(\mathrm{g} / \mathrm{kg}): 810$ barley grain, 170 soya-bean meal, 12 limestone, 8 sodium chloride, I vitamin and mineral mixture. The vitamin mixture was calculated to supply a vitamin A activity equivalent to $30 \mu \mathrm{g}$ retinol $/ \mathrm{kg}$ body-weight. Before the preparation of each batch of concentrates any remaining maize grain was removed from the pipes at the mixing plant. The concentrate mixture contained $106 \mu \mathrm{g} \beta$-carotene $/ \mathrm{kg}$ dry matter. Heifers of the control group were fed a gelatin capsule containing $0.3 \mathrm{mg} \beta$-carotene $/ \mathrm{kg}$ bodyweight while heifers of the experimental group received capsules containing a vitamin $\mathbf{A}$ activity equivalent to $36 \mu \mathrm{g}$ retinol $/ \mathrm{kg}$ body-weight. The capsules were fed daily in the morning except for the 'Saturday' capsules which were fed on Friday in the afternoon. Body-weight and peripheral plasma concentrations of $\beta$-carotene and retinol were determined at the beginning of the experiment and at $14 \mathrm{~d}$ intervals thereafter. Plasma carotene and retinol were extracted and separated by chromatography on alumina as described by Thompson et al. ( 1949). Retinol concentration was determined by the Carr-Price reaction.

The experiment was terminated when the heifers reached the average age of 17 months.

\section{Oestrous detection and insemination}

At the average age of 13.5 months all the heifers were moved into one pen and observations for the detection of oestrus began. Four times daily, at 06.00, 12.00, 18.00 and 24.00 hours a bull with a deviated penis was brought into the heifers' pen and left there for $30 \mathrm{~min}$. During this period standing-to-mounting animals, mounting, sniffing and butting were recorded. The beginning and end of oestrus were regarded as having occurred $3 \mathrm{~h}$ before and $3 \mathrm{~h}$ after the first and last observations of standing heat respectively. All heifers were observed for oestrus during one full oestrous cycle, after which they were inseminated. Insemination was consequently carried out only at the second detected standing heat. All heifers were inseminated within a period of $23 \mathrm{~d}$. The length of the oestrous cycle was calculated from the interval (d) between the beginnings of the standing heats of two consecutive oestrous periods. All inseminations were carried out with semen collected from a single ejaculate. During the oestrous period heifers were inseminated twice at an interval of I $2 \mathrm{~h}$ between inseminations. Pregnancy diagnosis by palpation was performed 40 or more $\mathrm{d}$ after insemination.

From the average age of 8 months the ovaries and uteruses of heifers were palpated weekly and from the age of 10.5 months until the beginning of inseminations twice weekly. To determine the time of ovulation after inseminations, ovaries were palpated every $4-\mathrm{I} 4 \mathrm{~h}$ beginning $24 \mathrm{~h}$ after the first detection of standing heat. Time of ovulation was regarded as the midpoint between the time when ovulation had not yet occurred and the time when the point of ovulation on the ovary could be palpated. In four heifers ovulation had occurred before the first palpation was performed; for these heifers time of ovulation was considered to be the time of the first palpation.

\section{Progesterone and $L H$ determinations}

From the beginning of the experiment until puberty peripheral plasma progesterone concentrations were determined once per week. Progesterone was determined using a radioimmunoassay technique as described elsewhere (Rosenberg et al. 1977). LH concentration in peripheral plasma was determined during the oestrous period when the first insemination 


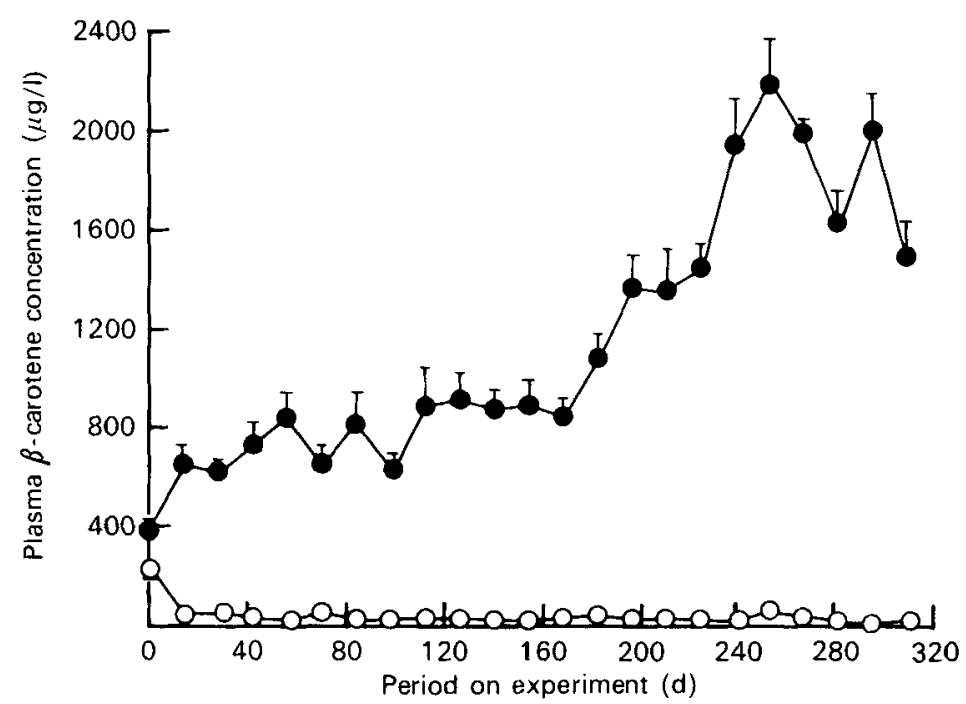

Fig. I. Peripheral plasma $\beta$-carotene concentration $(\mu \mathrm{g} / \mathrm{l})$ in heifers given concentrates and straw supplemented with vitamin $A(O)$ or $\beta$-carotene and vitamin $A(O)$. (For details of feeding regimen, see p. 354.) Points represent mean values, with their standard errors represented by vertical lines.

was carried out every $6 \mathrm{~h}$, from $24 \mathrm{~h}$ before the first detected standing heat until $48 \mathrm{~h}$ after this time.

LH was measured by double antibody radioimmunoassay (Niswender et al. 1969) using an antiserum to bovine LH (NIH-LH-B9) raised in guinea-pigs (Oxender et al. 1972) in our laboratory. Purified bovine LH (LER-I716-2) (supplied by NIAMDD, Bethesda, Md, USA) was used for radioiodination. The second antibody was prepared by immunizing a rabbit against guinea-pig $\gamma$-globulin (Miles Lab. Inc., Elkhart, Ind, USA). The assay detected as little as $0.7 \mathrm{ng} \mathrm{LH}(\mathrm{NIH}-\mathrm{LH}-\mathrm{B} 9)$ using an antiserum dilution of $\mathrm{I}: 7500(\mathrm{v} / \mathrm{v})$. The specificity of the antiserum was tested by assaying bovine prolactin (NIH-P-B4), Follicle Stimulating Hormone FSH (NIH-FSH-BI), Thyroid Stimulating Hormone, TSH (NIH-TSH-B7) and growth hormone GH (NIH-GH-BI003A) in the LH assay. The assay of $\mathrm{I} \mu \mathrm{g}$ of prolactin, GH and FSH resulted in $\mathrm{I} \cdot 5$, 10 and $\mathrm{II} \cdot 5 \mathrm{ng}$ equivalents $\mathrm{LH}$ respectively, while I $\mu \mathrm{g}$ TSH resulted in $350 \mathrm{ng}$ equivalent $\mathrm{LH}$, probably due to the contamination of the TSH preparation with immunologically-active $\mathrm{LH}$.

The LH concentrations in all serum samples which were assayed in the present experiment were measured in a single assay, which had an intra-assay coefficient of variation of $9.6 \%$.

\section{RESULTS}

\section{$\beta$-carotene and retinol plasma concentrations}

The peripheral plasma concentrations of $\beta$-carotene and retinol are shown in Figs. I and 2. Within 6 weeks of the beginning of the experiment, average $\beta$-carotene concentration in plasma of heifers of the experimental group reached the level of $30 \mu \mathrm{g} / \mathrm{l}$. At the same time, plasma $\beta$-carotene of the heifers in the control group increased to the level of $740 \mu \mathrm{g} / \mathrm{l}$. Thereafter the average level of $\beta$-carotene in plasma fluctuated between 20 and $60 \mu \mathrm{g} / 1$ in the experimental group and $630-2190 \mu \mathrm{g} / \mathrm{l}$ in the control group. Plasma concentration of retinol was similar in both groups. At 6 weeks after the beginning of the experiment it reached the level of $200 \mu \mathrm{g} / \mathrm{l}$ plasma; thereafter it fluctuated between I 70 and $350 \mu \mathrm{g} / \mathrm{l}$. 


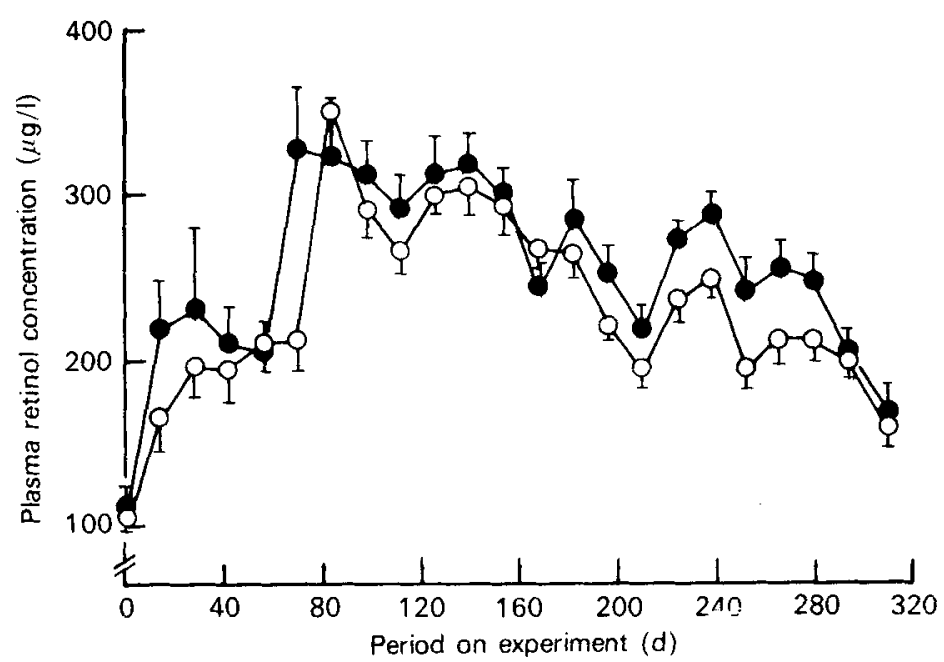

Fig. 2. Peripheral plasma retinol concentration $(\mu \mathrm{g} / \mathrm{l})$ in heifers given concentrates and straw supplemented with vitamin $\mathrm{A}(\mathrm{O})$ or $\beta$-carotene and vitamin $\mathrm{A}(O)$ ). (For details of feeding regimen, see p. 354.) Points represent mean values, with their standard errors represented by vertical lines.

\section{Reproductive phenomena}

The appearance and duration of the reproductive phenomena recorded were similar for heifers of both groups (Tables I and 2). Age at puberty as reflected by age at first ovulation was identical for both groups. All heifers exhibited the normal pattern of sexual behaviour; all the possible oestrous periods were detected and they were all accompanied by standing heat. The duration of oestrus was similar in heifers of both groups. Oestrous cycles of heifers of the experimental groups were on the average longer by $I \mathrm{~d}$ than those of the controls; this difference, however, is not significant. Ovarian cysts were palpated in one heifer of the control group; in this heifer a cyst was found on two occasions, $28 \mathrm{~d}$ apart. In all other heifers the reproductive organs were found to be normal.

All heifers conceived after one or two inseminations, conception rate being similar in both groups (Table 2). The length of the interval between LH peak and ovulation at first insemination was longer in heifers of the control group (Table I); this difference was not significant $(0.05<P<0.1)$. The progesterone concentration during the oestrous cycle preceding the first insemination is shown in Fig. 3. Plasma progesterone concentrations during this cycle and throughout the experiment were similar in heifers of both groups. Likewise, average peak LH levels in both groups were similar.

\section{Rate of growth}

During the experimental period of $308 \mathrm{~d}$ the mean $( \pm \mathrm{SE}$ ) daily gain of the experimental and control heifers was $0.75 \pm 0.02$ and $0.81 \pm 0.02 \mathrm{~kg}$ respectively $(P<0.02)$. Most of the difference occurred during the last 3 months of the experiment, i.e. after conception. During this period, the mean $( \pm \mathrm{SE}$ ) daily gain of the experimental and control heifers was $0.62 \pm 0.05$ and $0.8 \mathrm{I} \pm 0.05 \mathrm{~kg}$, respectively. 


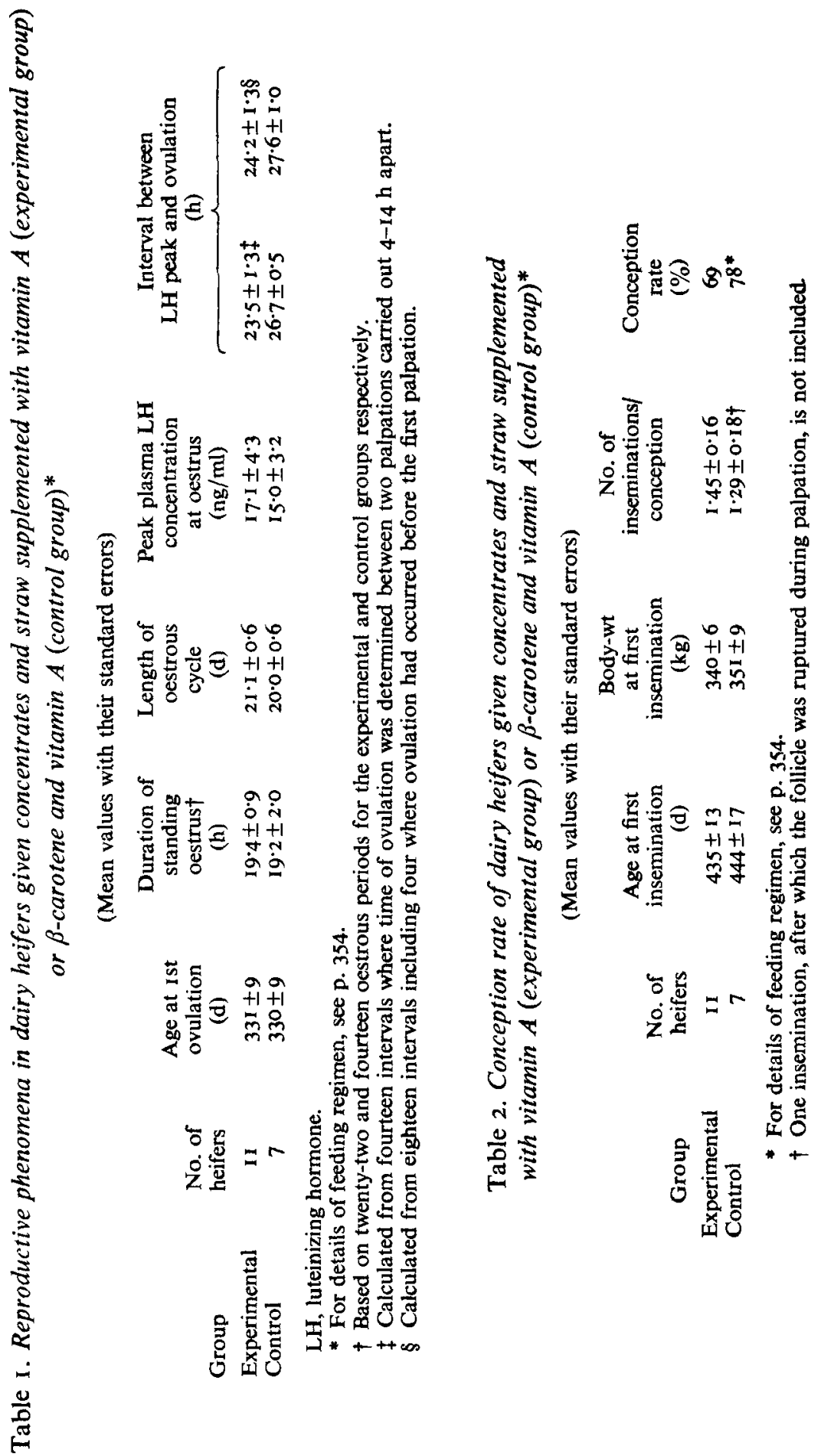




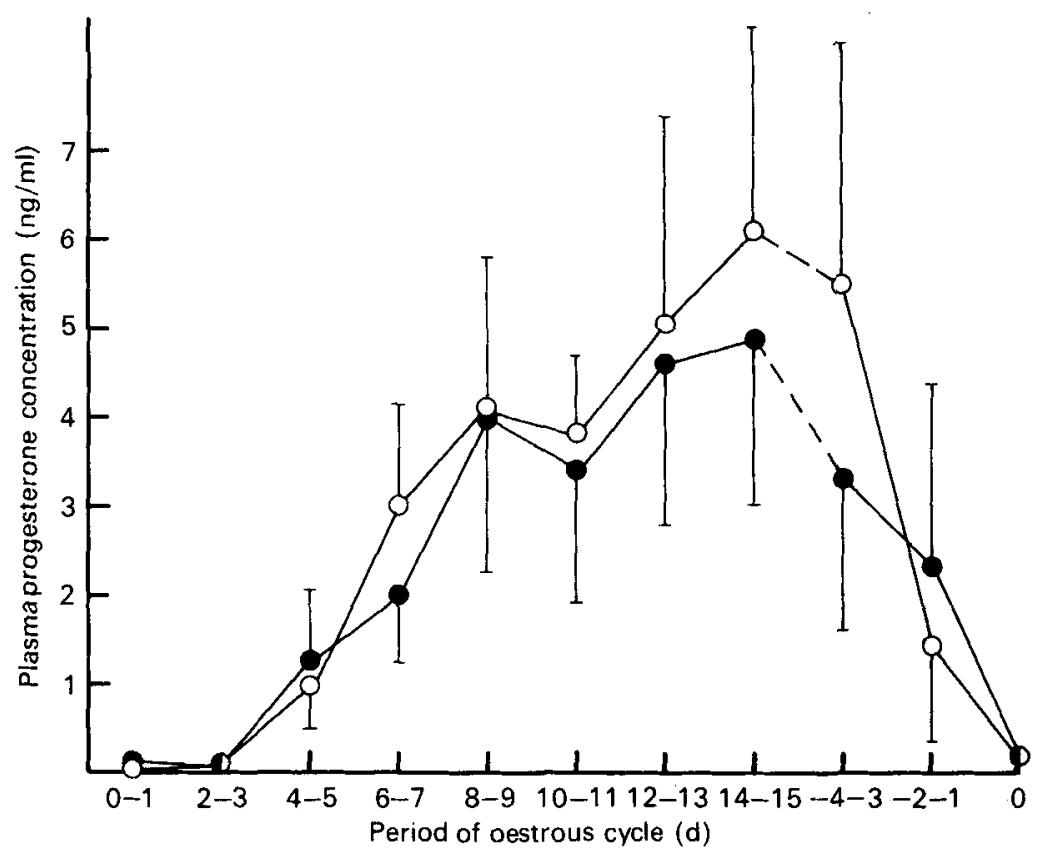

Fig. 3. Peripheral plasma progesterone concentration $(\mathrm{ng} / \mathrm{ml})$ during the oestrous cycle preceding the first insemination of heifers given concentrates and straw supplemented with vitamin $A(O)$ or $\beta$-carotene and vitamin $A(O)$. (For details of feeding regimen, see p. 354.) Points represent mean values with their standard errors represented by vertical lines.

\section{DISCUSSION}

The concentration of $\beta$-carotene in the corpus luteum of the cow is higher than that found in other organs of the cow or in corpora lutea of other species (Brüggemann \& Niesar, 1957; Ahlswede \& Lotthamer, 1977). Anwandter Quentin (1974) found that in summer this concentration reached an average level of $74.3 \mu \mathrm{g} / \mathrm{g}$ fresh tissue during the period of maximal luteal development. It has been suggested that in the cow $\beta$-carotene may have a specific effect in addition to its role as precursor of vitamin A (Meyer et al. 1975; Lotthamer et al. 1976).

In the present experiment, heifers deprived of $\beta$-carotene had considerably lower $\beta$ carotene concentrations in plasma than the heifers in the experiments of Meyer et al. (1975) and Lotthamer et al. (1976) (20-60 $\mu \mathrm{g} / 1 \mathrm{v}$. 100-300 $\mu \mathrm{g} / \mathrm{l})$. This is probably due to the fact that while the heifers in experiments of Meyer et al. (1975) and Lotthamer et al. (1976) were given concentrates and hay from the previous crop, our animals were given concentrates and straw only.

Even though the plasma $\beta$-carotene concentrations were very low, the heifers in the present experiment did not exhibit any of the impairments in reproductive function which were reported in the previous papers (Meyer et al. 1975; Lotthamer et al. 1976). No ovarian cysts were found in the experimental heifers of the present experiment and the difference in the length of the oestrous cycle between the groups was not significant (Table I).

In the present experiment, in which observations for oestrus were carried out four times daily, no differences in the length or intensity of oestrus were observed between the experimental groups (Table I). This disagrees with the results reported by Meyer et al. (1975) and Lotthamer et al. (1976), which are based on daily observations between 07.00 
and 16.00 hours and on rectal palpations. Likewise, in contrast to the results obtained by Schams et al. (1977), we found that the interval between the LH peak and ovulation was similar in both groups (Table $\mathbf{I}$ ).

The conception rate in the two groups of heifers was similar (Table 2). This might be a result of the fact that all animals in the present experiment were inseminated after standing heat while Lotthamer et al. (I976) inseminated the heifers of the experimental group on the basis of rectal inspections rather than behavioural signs of oestrus. It is, however, possible that using a teaser bull during observations may have improved oestrous detection (Ermacenkov, 1960; Ayalon \& Weis, 1970; Eger et al. 1975).

It is rather surprising that heifers given $\beta$-carotene had a higher growth rate than the experimental heifers. Since, during the last 4 months of the experiment, all heifers of both groups were kept in one pen and fed from one open trough along the shed, it is possible that the control heifers consumed more food than the experimental heifers. Although all heifers were stanchioned when concentrates were fed, heifers could consume food given to their neighbours.

Under the conditions prevailing in this experiment, which ensured a strict carotene deprivation, feeding a diet with a very low $\beta$-carotene content did not impair any of the measured reproductive functions. A possible effect of a $\beta$-carotene-deficient diet on appetite, food utilization or daily gain warrants further investigation.

The authors thank the staff of the Bet Dagan experimental farm for taking good care of the heifers, Messrs Mara Heller, Esther Yizreeli, M. Kaim, A. Mayk and I. Flamenbaum for skilled technical assistance and Hoffmann-La Roche and Co., Basel, Switzerland, for the gift of the water-dispersible vitamin $A$ and $\beta$-carotene concentrates; also the National Institute of Arthritis, Metabolism and Digestive Diseases (NIAMDD), Bethesda, Maryland, USA for their generous gifts of bovine pituitary hormones used in this experiment.

\section{REFERENCES}

Agricultural Research Council (1965). The Nutrient Requirements of Farm Livestock No. 2, Ruminants. London: HM Stationery Office.

Ahlswede, L. \& Lotthamer, K. H. (1977). Dt. tierärztl. Wschr. 85, 7.

Anwandter Quentin, C. G. (1974). Progesteron und $\beta$-Carotin-Gehalt des bovinen Corpus Luteum wahrend der verschiedenen Phasen des Sexualzyklus in Abhangigkeit von der Jahreszeit. DMV thesis, Hannover School of Veterinary Medicine.

Ayalon, N. \& Weis, Y. (1970). Refuah vet. 27, 22.

Brüggemann, J. \& Niesar, K. H. (1957). Vitam. Horm., Lpz. 7, 10.

Eger, S., Schindler, H. \& Amir, S. (1975). Hassadeh 55, I 851 .

Ermacenkov, N. N. (1960), cited by Anim. Breed. Abstr. (1962), 30, I721.

Lotthamer, K. H., Ahleswede, L. \& Meyer, H. (1976). Dt. tierärztl. Wschr. 83, 353.

Meyer, H., Ahlswede, L. \& Lotthamer, K. H. (1975). Dt. tierärztl. Wschr. 82, 444.

National Research Council. (1971). Nutrient Requirements of Dairy Cattle, 4th ed. Washington, DC: National Academy of Sciences.

Niswender, G. D., Reichert, L. E., Midgley, A. R. \& Nalbandov, A. V. (1969). Endocrinology 84, 166.

Oxender, W. D., Hafs, H. D. \& Edgerton, L. A. (1972). J. Anim. Sci. 35, 5 I.

Rosenberg, M., Herz, Z., Davidson, M. \& Folman, Y. (1977). J. Reprod. Fert. 5I, 363.

Schams, D., Hoffmann, B., Lotthamer, K. H. \& Ahlswede, L. (1977). Dt. tierärztl. Wschr. 84, 307.

Thompson, S. Y., Ganguly, J. \& Kon. S. K. (1949). Br. J. Nutr. 3, 50. 